\title{
Quality parameters of some Brazilian panettones
}

\author{
Beatriz Valcárcel-Yamani, Suzana Caetano da Silva Lannes*
}

Pharmaceutical-Biochemical Technology Department, Faculty of Pharmaceutical Sciences, University of São Paulo, SP, Brazil

\begin{abstract}
In panettone, physical and chemical properties can determine the quality attributes in addition to consumer acceptability. The aim of this work was to assess the quality attributes of nine commercial samples of Brazilian panettone. Samples were characterized according to their physicochemical (moisture and color) aspects, quality attributes (specific volume, density and texture) and image analysis. The results of the statistical analysis (ANOVA and Tukey) showed significant differences $(\mathrm{p} \leq 0.05)$ among the samples. Differences were observed in the specific volume and density. Samples showed moisture values between $22.83 \%$ and $26.86 \%$. The texture analysis showed greater variation in values of crumb firmness (from $2.14 \mathrm{~N}$ to $7.55 \mathrm{~N}$ ). Significant differences in crust ( $\mathrm{L}^{*}$ values between 31.58 and 44.85 , $\mathrm{a}^{*}$ between 12.34 and 16.47 and $b^{*}$ between 27.15 and 37.28 ) and crumb ( $\mathrm{L}^{*}$ values between 64.48 and 72.34 , $\mathrm{a}^{*}$ between -0.82 and 3.79 and $b^{*}$ between 33.43 and 40.97) color parameters were found for all samples. Through the image analysis, variability in the crumb structure was observed; however, the statistical analysis showed no significant differences between samples.
\end{abstract}

Uniterms: Panettone/physical and chemical properties. Panettone/qualitative analysis. Panettone/texture. Panettone/color. Panettone/image analysis.

No panetone, propriedades físicas e químicas podem determinar além dos atributos de qualidade, a aceitabilidade pelos consumidores. O objetivo do presente trabalho é avaliar atributos de qualidade em nove amostras comerciais de panetone brasileiro. As amostras foram caracterizadas quanto a aspectos físico-químicos (umidade e cor), atributos de qualidade (volume específico, densidade e textura) e análise de imagem. Os resultados das análises estatísticas (ANOVA e Tukey) mostraram diferenças significativas $(\mathrm{p} \leq 0,05)$ entre as amostras. Diferenças no volume específico e densidade foram observadas. As amostras apresentaram valores de umidade entre $22,83 \%$ e 26,86\%. A análise de textura do miolo mostrou elevada variação nos valores de firmeza (entre $2,14 \mathrm{~N}$ e 7,55 N). Diferenças significativas nos parâmetros de cor, para crosta (valores de $L^{*}$ entre 31,58 e 44,85 , a* entre 12,34 e 16,47 e b* entre 27,15 e 37,28 ) e miolo (valores de $\mathrm{L}^{*}$ entre 64,48 e 72,34, a* entre $-0,82$ e 3,79 e b* entre 33,43 e 40,97), foram encontrados em todas as amostras. Por meio da análise de imagem observou-se variabilidade na estrutura do miolo, porém a análise estatística não mostrou diferenças significativas entre as amostras.

Unitermos: Panetone/propriedades físicas e químicas. Panetone/análise qualitativa. Panetone/textura. Panetone/cor. Panetone/análise de imagem.

\section{INTRODUCTION}

According to National Agency of Sanitary Vigilance (ANVISA, 2005), bread is the product obtained by baking a dough under technologically appropriate conditions, fermented or otherwise, prepared from wheat flour and/

\footnotetext{
*Correspondence: S.C.S. Lannes. Laboratório de Tecnologia de Alimentos III, Departamento de Tecnologia Bioquímica-Farmacêutica, Faculdade de Ciências Farmacêuticas, Universidade de São Paulo. Av. Prof. Lineu Prestes, 580, Butantã, 05508-000 - São Paulo SP, Brazil. E-mail: scslan@usp.br
}

or other flours containing natural gluten-forming proteins or added and water, and may contain other ingredients. Bread can also contain coatings, fillings, and vary in shape and texture.

Panettone is a traditional oven-baked sweet bread originating in Milan, and prepared specially for the season of Christmas and New Year in Italy and in Latin American countries. Panettone is prepared from a sweet dough by adding optional ingredients such as candied fruit, raisins, almonds or chocolate (Garofalo et al., 2008; Benejam, Esteffolani, León, 2009). 
Generally, in panettone elaboration, sponge and sourdough methods are employed (Benejam, Esteffolani, León, 2009). The sponge which is used as a substitute for yeast consists of a simple mixture of flour, water and yeast that is added to the dough before the mixing and baking process (Lai, Lin, 2006). Sourdough is a spontaneously fermented mixture of flour and water, or more often, a mixture inoculated with a wild microbial starter (yeast and lactic acid bacteria) (Gänzle, Ehmann, Hammes, 1998; Vogel et al., 1999). This latter, commonly called "motherdough" or "massa-madre", is a continuously reproduced sourdough which is renewed cyclically by using strict conditions of recipe and ripening, and is traditionally used as an inoculum for the subsequent doughs (Randazzo et al., 2005). These methods help to improve the aroma, because of the release of volatile and aromatic compounds due to a long fermentation (Hansen, Hansen, 1996).

Contrary to bread, panettone is commonly a product that keeps its quality during storage and can be consumed a long period after being produced; this period can even reach a few months. It seems that this period of storage, which could be called an apparent "maturation", could even help to accentuate the flavor in the product and, in that sense, be beneficial to the final product. This might be because, in the bakery industry, several additives such as oxidizing agents, emulsifiers and enzymes are used to improve dough properties, process tolerance and bread quality, and in particular to optimize shelf life quality (Hoseney, 1994; Benejam, Esteffolani, León, 2009).

Because a growing number of brands of these products are available in the Brazilian market, an analysis of physical and chemical properties could help to determine their identity and quality. Esteller and Lannes (2005) proposed some parameters for fixing the identity and quality of bakery products. These parameters of analysis such as texture, moisture, volume, color, and image analysis were shown to be useful for further characterization of the analyzed products.

In bakery products, textural attributes are key characteristics that consumers appreciate. The texture of a food is derived from its structure (Bourne, 2002) and is defined as the set of mechanical, geometrical and superficial attributes, perceived by mechanical, tactical, and even visual and auditive receptors (Rosenthal, 2001; Esteller, Amaral, Lannes, 2004). These properties are mainly related to the deformation, disintegration and food movement under the action of a force which can be objectively measured as a function of mass, time and distance (Bourne, 2002). Texture profile analysis (TPA), originally designed for the subjective assessment of foods, was adapted for the objective measurement based on two successive compressions on the same sample with forces that cause some irreversible changes to the tested food (Cauvain, 2009).

Color is a critical parameter in baked goods that determines its acceptance by the consumer (Giese, 2000) and results from the presence of colored compounds existing in the product (natural pigments) or the addition of synthetic colorants. Besides these compounds, the presence of sugars in the formulation accelerates the Maillard reaction, leading to a progressive browning of the crust and crumb which may be unwanted. For quality control in the production and marketing of foods, color can be measured by secure instrumental procedures, using equipment such as a colorimeter which measures $\mathrm{L}^{*}, \mathrm{a}^{*}$ and $b^{*}$ coordinates and is largely used for color evaluation (Esteller, Lima, Lannes, 2006).

Crumb cellular structure is an important quality criterion used in commercial baking and research laboratories to judge bakery product quality alongside taste, crumb color and crumb physical texture. It is believed that the crumb cellular structure has a considerable importance in defining bakery product quality since other quality attributes in these products, such as volume, depend on crumb characteristics. The evaluation of the mechanical properties of crumb could be important also for assessing the effects of changes in various dough ingredients and processing conditions, and also the effect of shelf life on the acceptability of bakery products to the consumer (Scanlon, Zghal, 2001). In recent years, there has been increasing interest in adapting digital image analysis for the objective and quantitative evaluation of crumb features (Ribotta et al., 2010).

The aim of the present study was to assess physicochemical (moisture and color) aspects and quality attributes (specific volume, density and texture) in commercial Brazilian panettones.

\section{MATERIAL AND METHODS}

\section{Samples}

Samples of commercial products were purchased at a local market in São Paulo. Nine samples of fruit panettone were selected and randomly marked as: A, B, C, D, E, F, G and $\mathrm{H}$; I was a panettone without fruit. The samples, when analyzed, were between 1 (D and G) and 3 (A, B, C, E, F, $\mathrm{H}$ and I) months of manufacture. Manufacturers stipulate at least 6 months of validity for these products.

\section{Specific volume and density}

Samples were weighed $(\mathrm{g})$ and loaf volume $(\mathrm{mL})$ 
was determined using the rapeseed displacement method (Nishita, Roberts, Bean, 1976). Specific volume (mL/g) and density $(\mathrm{g} / \mathrm{mL})$ were calculated. Measurements of the specific volume and density were performed in six replicates.

\section{Moisture content}

The moisture content of samples was determined by AACC standard method 44-15A (1995). Samples were ground and homogenized (crust + crumb), and were weighed $(10 \mathrm{~g})$ in aluminum capsules and dehydrated in an oven at $105^{\circ} \mathrm{C}$ for 2 hours. After dehydration, samples were placed in desiccators until reaching room temperature and weighed. The weighing and drying proceduree were repeated until a constant value was obtained. Moisture measurements were made in triplicate.

\section{Texture}

Texture profile analysis (TPA) parameters were determined using a TA-XT2 Texturometer (Stable Microsystems Ltd, UK). Instrument settings were: probe compression platens $\mathrm{P} / 75 \varnothing 75 \mathrm{~mm}$, double compression speed $2.0 \mathrm{~mm} / \mathrm{s}$, distance $40 \%$, force $100 \mathrm{~g}$ and time $5 \mathrm{~s}$. The textural parameters hardness, cohesiveness, springiness, chewiness and adhesiveness were quantified. Samples (slices of $40 \mathrm{~mm} \times 40 \mathrm{~mm}$ ), removed from the central portion were kept in the original packing and measurements were made as quickly as possible to prevent moisture loss. Texture parameters were measured in six replicates.

\section{Crumb and crust color}

The color parameters of the crumb and crust were determined using a HunterLab spectrophotometer UltraScan ${ }^{\mathrm{TM}} \mathrm{XE}$ model, with an observer angle of $10^{\circ}$ and D65 illuminant at $420 \mathrm{~nm}$. The color was recorded using CIE-L* $a * b *$ uniform color space (CIE-Lab), where L* indicates lightness, $\mathrm{a}^{*}$ indicates hue on a green $(-)$ to red $(+)$ axis, and $b^{*}$ indicates hue on a blue $(-)$ to yellow $(+)$ axis. Color measurement of the samples was performed three times.

\section{Image analysis of crumb structure}

For each sample, two $(60 \mathrm{~mm} \times 60 \mathrm{~mm})$ slices were obtained from the central region. Crumb cell analysis was performed by scanning the longitudinal section (slices cut vertically) of samples with an HP PSC 2355 scanner. JPEG image file formats were analyzed with image analysis software (Image J 1.41o; National Institutes of Health, USA). A single field of view was evaluated for each image. Images were taken from the center of the slice. The crumb cell features chosen were the total number of cells (n), the total cell area $\left(\mathrm{mm}^{2}\right)$, the mean cell area $\left(\mathrm{mm}^{2}\right)$ and diameter $(\mathrm{mm})$. The characterization of the crumb structure was performed in triplicate.

\section{Statistical analysis}

Statistical analyses of the samples were performed using the software Statistica 7.1 (StatSoft Inc., Tulsa, OK, USA). Results are expressed as mean values \pm standard deviation (SD). The Hartley test was applied to check for the homogeneity of variances, and one-way ANOVA and Tukey's HSD post hoc tests were then conducted to identify contrasts among samples with $95 \%$ confidence.

\section{RESULTS AND DISCUSSION}

\section{Specific volume, density and moisture content}

The results described in Table I show the specific volume, density and moisture of the nine panettone samples. At a macroscopic level, bread consists of two phases: a fluid (air), formed by varying sizes of isolated bubbles, and a solid portion (cell wall material) that is interconnected. The total of both phases will result in the volume. Both the specific volume and density indicate the relationship between solids and the fraction of air (Scanlon, Zghal, 2001). According to the results, differences were observed in specific volume and density among the samples. These differences were statistically significant $(\mathrm{p} \leq 0.05)$ for samples $\mathrm{A}$ and $\mathrm{C}$ and for sample I which did not contain fruit. Samples A, C and I were characterized by presenting the lowest specific volume $(3.82 \mathrm{~mL} / \mathrm{g}, 3.18 \mathrm{~mL} / \mathrm{g}$ and $4.47 \mathrm{~mL} / \mathrm{g}$, respectively). The highest density was observed in sample C $(0.32 \mathrm{~g} / \mathrm{mL})$.

Variations in the final volume of the samples can be determined by various external factors such as the type of process, temperature and time, as well as factors related to raw materials such as fats (O'Brien et al., 2000), milk (Gallagher, Gormley, Arendt, 2003; Kenny et al., 2000), sugars and salt, among others. According to the storage time of those samples with significant statistical variability, a relation indicating the influence of storage time on the volume and density was not observed. Because of the fact that panettone is characterized for presenting a highly aerated structure, it is important to indicate that 
TABLE I - Specific volume, density, and moisture content of panettone samples

\begin{tabular}{lccc}
\hline Samples & Specific volume $(\mathrm{mL} / \mathrm{g})$ & Density $(\mathrm{g} / \mathrm{mL})$ & Moisture $(\%)$ \\
\hline A & $3.82^{\mathrm{bc}} \pm 0.28$ & $0.26^{\mathrm{b}} \pm 0.02$ & $23.66^{\mathrm{cd}} \pm 0.46$ \\
B & $5.02^{\mathrm{a}} \pm 0.51$ & $0.20^{\mathrm{c}} \pm 0.02$ & $23.02^{\mathrm{cd}} \pm 0.44$ \\
C & $3.18^{\mathrm{c}} \pm 0.33$ & $0.32^{\mathrm{a}} \pm 0.03$ & $22.83^{\mathrm{d}} \pm 0.41$ \\
D & $4.70^{\mathrm{a}} \pm 0.46$ & $0.21^{\mathrm{c}} \pm 0.03$ & $25.34^{\mathrm{ab}} \pm 0.38$ \\
E & $4.79^{\mathrm{a}} \pm 0.31$ & $0.21^{\mathrm{c}} \pm 0.01$ & $23.09^{\mathrm{cd}} \pm 0.43$ \\
F & $4.75^{\mathrm{a}} \pm 0.48$ & $0.21^{\mathrm{c}} \pm 0.02$ & $23.16^{\mathrm{cd}} \pm 0.14$ \\
G & $5.13^{\mathrm{a}} \pm 0.46$ & $0.20^{\mathrm{c}} \pm 0.02$ & $26.86^{\mathrm{a}} \pm 1.34$ \\
H & $4.58^{\mathrm{a}} \pm 0.67$ & $0.22^{\mathrm{c}} \pm 0.03$ & $25.66^{\mathrm{ab}} \pm 0.63$ \\
I & $4.47^{\mathrm{ab}} \pm 0.41$ & $0.23^{\mathrm{c}} \pm 0.03$ & $24.62^{\mathrm{bc}} \pm 0.12$ \\
\hline
\end{tabular}

Values followed by different letters, in the same column, present significant differences ( $\mathrm{p} \leq 0.05)$ according to the Tukey test.

the presence of candied fruit and raisins also might be devaluating the actual volume of the samples.

The moisture content, associated with softness and ease of chewing, can vary according to the type of product and process conditions. An excess of moisture increases the stickiness of the dough and accelerates microbiological deterioration. The values of moisture described in Table I show values between $22.83 \%$ (sample C) and $26.86 \%$ (sample G). These values are in accordance with that established in Brazilian legislation - RDC no. 90 (ANVISA, 2000), which indicates that the moisture level in panettone should not exceed $30 \%$. Compared with traditional bread, where the moisture is situated close to $38 \%$, these levels may be considered low. However, this difference could be related mainly to the fact that panettone is a product which normally has to be preserved for a long time. On the other hand, several factors related to storage conditions, packaging, temperature and relative moisture, among others, may also influence the final moisture content (Cauvain, 1998).

\section{Texture}

The results obtained for texture analysis are presented in Table II. Texture, volume and structure are important properties of bakery products. In the crumb, texture is related to mechanical properties. The maximum force measured for bakery products is dependent on the formulation. Some ingredients, such as flour, sugars, fats, emulsifiers, enzymes, the addition of gluten and flour improvers, together with the moisture of dough and storage (time of the product manufacturing and packaging), can affect the final product (Esteller, Lannes, 2005; Scanlon, Zghal, 2001).

The texture analysis of the samples showed a higher crumb firmness in sample $\mathrm{C}(7.55 \mathrm{~N})$, which was close to those observed in Italian bread crumbs $(7.42 \mathrm{~N})$ analyzed by Esteller and Lannes (2005). On the other hand, the lowest values of firmness or greatest softness were observed in samples E $(2.14 \mathrm{~N}), \mathrm{H}(2.17 \mathrm{~N})$ and $\mathrm{I}(2.60 \mathrm{~N})$. However, these values are higher when compared to the crumb firmness in French bread samples $(0.72 \mathrm{~N})$, sliced bread $(1.56 \mathrm{~N})$, hot dog/hamburger buns $(1.44 \mathrm{~N})$ and ciabatta $(1.36 \mathrm{~N})$ (Esteller, Lannes, 2005).

Crumb firmness or softness is a property that has attracted the most attention in bakery product assessment because of its close association with the human perception of freshness (Cauvian, 2009). The loss of crust crispness is characteristic for panettone. It is because crust crispiness is perceived only for a short time after baking (AltamiranoFortoul, Rosell, 2011).

Cohesiveness values showed variation between the samples (Table II). Increased values of cohesiveness were observed in samples $\mathrm{H}$ and $\mathrm{E}$ ( 0.51 and 0.48 respectively). Nevertheless samples B and C showed lower values (0.38 respectively). Low values of cohesiveness indicate a loss of intermolecular attraction between ingredients, loss of moisture and a tendency to flaking in crust and crumb. Dough development occurs during mixing after the incorporation of water. Disulfide, hydrogen and ionic bonds maintain cohesiveness and contribute to gas retention during baking. During storage, changes affecting these linkages (such as water migration, starch crystallization, fat hydrolysis) lead to a disarrangement of the structure (Hoseney, 1994; Esteller, Amaral, Lannes, 2004).

The results of springiness tests indicated higher values for samples $G$ and $H$ ( 0.71 for both of them) and lower values for samples $\mathrm{E}$ and $\mathrm{F}$ ( 0.52 and 0.43 , respectively). Comparing the chewiness, higher values 
were observed in samples C and D $(1.68 \mathrm{~N}$ and $1.44 \mathrm{~N}$, respectively). On the other hand, lower values were observed in samples E $(0.51 \mathrm{~N}), \mathrm{H}(0.7 \mathrm{~N})$ and $\mathrm{I}(0.73 \mathrm{~N})$. Low values of springiness and high chewiness are usually indicators of storage time (Esteller, Amaral, Lannes, 2004). However, in this study, this ratio was not observed since the samples showed less or similar storage time at the moment of analysis. In sample $\mathrm{C}$, chewiness and firmness were greater and may correlate with a lower moisture content. Samples of aged and dry bakery products require more salivation and mastication. In products with complex formulations such as panettone, chewiness is mainly affected by the fat and sugar contents (Benejam, Esteffolani, León, 2009).

\section{Color}

Results of crust and crumb color measurements are shown in Table III. In bakery products, color appears in the final period of baking. During the cooking process, an increase in temperature leads to the inactivation of yeast and enzymes, starch gelatinization, changes in gluten proteins, water evaporation from the surface layers causing crust development and the Maillard reaction responsible for the color and flavor. In this process, a very dark crust color is a result of very high oven temperatures or excessive cooking. Nevertheless, a light color is a sign of long fermented doughs, a cold oven, or even insufficient baking time (Farahnaky, Majzoobi, 2008; Esteller, Lima, Lannes, 2006).

In the crust, where the presence of sugars accelerates caramelization and Maillard reactions during the baking process, the lowest values of $\mathrm{L}^{*}$ were for samples $\mathrm{A}\left(\mathrm{L}^{*}=35.53\right), \mathrm{B}\left(\mathrm{L}^{*}=33.95\right), \mathrm{C}\left(\mathrm{L}^{*}=31.58\right)$ and $\mathrm{E}\left(\mathrm{L}^{*}=33.45\right)$; sample $\mathrm{D}\left(\mathrm{L}^{*}=44.85\right)$ showed the highest value. Elevated values of a* (red deviation), indicating a darker color, were observed for the crusts of $\mathrm{C}\left(\mathrm{a}^{*}=15.48\right), \mathrm{D}\left(\mathrm{a}^{*}=16.47\right)$ and $\mathrm{F}\left(\mathrm{a}^{*}=15.26\right)$. The highest value of $b^{*}$ also was found in sample D (37.28).

Moreover, in the crumb, higher values of lightness (L*), which indicates higher light reflectance in products with lighter color and lower in sugars, were found for the crumbs of samples A $\left(\mathrm{L}^{*}=70.61\right)$ and $\mathrm{D}\left(\mathrm{L}^{*}=72.34\right)$. Higher $\mathrm{a}^{*}$ value, indicating some interactions among ingredients activated by heat, was observed for sample $\mathrm{C}$ $\left(a^{*}=3.79\right)$. In sample $D$, where the lowest crumb color was observed, $\mathrm{a}^{*}$ value was negative $\left(\mathrm{a}^{*}=-0.82\right)$. Higher value of $b^{*}$ (with a strong deviation to yellow), typical of bakery products rich in proteins, sugars and carotenoids was found for the crumb of sample $\mathrm{C}\left(\mathrm{b}^{*}=40.97\right)$. According to Esteller and Lannes (2005), some variations in the values of $a^{*}$ and $b^{*}$ can also be related to porosity, and in the case of panettone, the presence of candied fruit and raisins.

\section{Image analysis of crumb structure}

The major features of the internal character of bread and fermented products are generally related to size, number and distribution of cells in the crumb, crumb color, and any major quality defects such as holes visible in a cross section of the product (Cauvain, 2009).

The structure of a loaf of bread is an organized system that can tell much about the loaf. In an aqueous environment with no added stress, gas cells will always be round. Such cells are clearly seen in cakes or in bread made with continuous bread-making systems. These cells have the minimum surface area, and therefore, the least energy. In conventionally made bread, many of the cells are elongated, indicating that a considerable force was put

TABLE II - Crumb texture of panettone samples

\begin{tabular}{lccccc}
\hline Sample & Firmness (N) & Springiness & Cohesiveness & Chewiness (N) & Resilience \\
\hline A & $3.36^{\mathrm{d}} \pm 0.27$ & $0.64^{\mathrm{abc}} \pm 0.04$ & $0.44^{\mathrm{abcd}} \pm 0.02$ & $0.95^{\mathrm{de}} \pm 0.11$ & $0.12^{\mathrm{ab}} \pm 0.01$ \\
$\mathrm{~B}$ & $5.41^{\mathrm{b}} \pm 0.98$ & $0.60^{\text {cd }} \pm 0.10$ & $0.38^{\mathrm{cd}} \pm 0.04$ & $1.25^{\mathrm{bcd}} \pm 0.20$ & $0.10^{\mathrm{b}} \pm 0.02$ \\
$\mathrm{C}$ & $7.55^{\mathrm{a}} \pm 0.64$ & $0.60^{\text {cd }} \pm 0.14$ & $0.38^{\mathrm{d}} \pm 0.04$ & $1.68^{\mathrm{a}} \pm 0.27$ & $0.11^{\mathrm{b}} \pm 0.01$ \\
D & $5.79^{\mathrm{b}} \pm 1.04$ & $0.61^{\mathrm{abcd}} \pm 0.11$ & $0.42^{\mathrm{bcd}} \pm 0.06$ & $1.44^{\mathrm{ab}} \pm 0.20$ & $0.10^{\mathrm{b}} \pm 0.02$ \\
E & $2.14^{\mathrm{e}} \pm 0.40$ & $0.52^{\mathrm{de}} \pm 0.10$ & $0.48^{\mathrm{ab}} \pm 0.05$ & $0.51^{\mathrm{f}} \pm 0.08$ & $0.14^{\mathrm{a}} \pm 0.02$ \\
F & $5.28^{\mathrm{b}} \pm 1.02$ & $0.43^{\mathrm{e}} \pm 0.05$ & $0.43^{\mathrm{abcd}} \pm 0.07$ & $1.00^{\text {cde }} \pm 0.15$ & $0.13^{\mathrm{ab}} \pm 0.02$ \\
G & $4.41^{\mathrm{c}} \pm 0.54$ & $0.71^{\mathrm{a}} \pm 0.03$ & $0.41^{\mathrm{bcd}} \pm 0.02$ & $1.29^{\mathrm{bc}} \pm 0.17$ & $0.11^{\mathrm{b}} \pm 0.01$ \\
$\mathrm{H}$ & $2.17^{\mathrm{e}} \pm 0.34$ & $0.71^{\mathrm{a}} \pm 0.11$ & $0.51^{\mathrm{a}} \pm 0.04$ & $0.78^{\mathrm{ef}} \pm 0.13$ & $0.14^{\mathrm{a}} \pm 0.02$ \\
I & $2.60^{\mathrm{de}} \pm 0.25$ & $0.61^{\mathrm{bcd}} \pm 0.04$ & $0.47^{\mathrm{abc}} \pm 0.04$ & $0.73^{\mathrm{ef}} \pm 0.08$ & $0.14^{\mathrm{a}} \pm 0.01$ \\
\hline
\end{tabular}

Values followed by different letters, in the same column, present significant differences ( $p \leq 0.05)$ according to the Tukey test. 
TABLE III - Crumb and crust color of panettone samples

\begin{tabular}{|c|c|c|c|c|c|c|}
\hline \multirow{2}{*}{ Sample } & \multicolumn{3}{|c|}{ Crust } & \multicolumn{3}{|c|}{ Crumb } \\
\hline & $\mathbf{L}^{*}$ & $a^{*}$ & $\mathbf{b}^{*}$ & $\mathbf{L}^{*}$ & a* & $\mathbf{b}^{*}$ \\
\hline A & $35.53^{\mathrm{cd}} \pm 2.28$ & $14.53^{\mathrm{bc}} \pm 0.24$ & $29.52^{\mathrm{bc}} \pm 1.46$ & $70.61^{\mathrm{ab}} \pm 1.31$ & $1.17^{\mathrm{de}} \pm 0.21$ & $39.06^{\mathrm{b}} \pm 1.68$ \\
\hline B & $33.95^{\mathrm{d}} \pm 2.30$ & $14.36^{\mathrm{bc}} \pm 0.57$ & $29.10^{\mathrm{bc}} \pm 2.85$ & $64.48^{\mathrm{f}} \pm 1.64$ & $2.58^{\mathrm{b}} \pm 0.46$ & $36.87^{\mathrm{d}} \pm 1.13$ \\
\hline $\mathrm{C}$ & $31.58^{\mathrm{d}} \pm 1.55$ & $15.48^{\mathrm{ab}} \pm 0.83$ & $27.98^{c} \pm 1.90$ & $67.28^{\mathrm{de}} \pm 1.10$ & $3.79^{\mathrm{a}} \pm 0.67$ & $40.97^{\mathrm{a}} \pm 1.03$ \\
\hline $\mathrm{D}$ & $44.85^{\mathrm{a}} \pm 3.32$ & $16.47^{\mathrm{a}} \pm 1.04$ & $37.28^{\mathrm{a}} \pm 3.22$ & $72.34^{\mathrm{a}} \pm 1.74$ & $-0.82^{\mathrm{f}} \pm 0.15$ & $33.43^{\mathrm{f}} \pm 1.00$ \\
\hline E & $33.45^{\mathrm{d}} \pm 1.71$ & $13.82^{\mathrm{c}} \pm 0.71$ & $28.11^{\mathrm{c}} \pm 1.40$ & $68.58^{\mathrm{bcd}} \pm 1.57$ & $1.84^{\mathrm{c}} \pm 0.35$ & $37.70^{\text {cd }} \pm 1.86$ \\
\hline $\mathrm{F}$ & $39.17^{\mathrm{bc}} \pm 1.36$ & $15.26^{\mathrm{ab}} \pm 0.62$ & $33.08^{b} \pm 0.56$ & $65.21^{\mathrm{ef}} \pm 1.51$ & $2.61^{b} \pm 0.49$ & $35.56^{\mathrm{e}} \pm 0.87$ \\
\hline G & $39.57^{\mathrm{bc}} \pm 2.48$ & $14.59^{\mathrm{bc}} \pm 0.39$ & $27.15^{\mathrm{c}} \pm 1.76$ & $68.39^{\mathrm{bcd}} \pm 1.55$ & $0.92^{\mathrm{e}} \pm 0.17$ & $34.55^{\mathrm{ef}} \pm 0.79$ \\
\hline $\mathrm{H}$ & $39.72^{\mathrm{bc}} \pm 2.40$ & $13.57^{\mathrm{cd}} \pm 0.67$ & $28.16^{c} \pm 2.52$ & $68.08^{\mathrm{cd}} \pm 1.24$ & $2.02^{\mathrm{c}} \pm 0.34$ & $39.01^{b} \pm 0.76$ \\
\hline I & $40.43^{b} \pm 2.22$ & $12.34^{\mathrm{d}} \pm 0.53$ & $28.77^{\circ} \pm 2.32$ & $69.62^{\mathrm{bc}} \pm 0.84$ & $1.41^{\mathrm{d}} \pm 0.19$ & $38.21^{\mathrm{bc}} \pm 0.44$ \\
\hline
\end{tabular}

Values followed by different letters, in the same column, present significant differences ( $\mathrm{p} \leq 0.05)$ according to the Tukey test.

on the cells. These kinds of cells can be seen in a spongeand-dough procedure. The degree of elongation is, then, a measure of the strength of the dough and a direct measure of the chewiness of the bread (Hoseney, 1994).

Moreover, a good quality bread usually has a crumb structure with high porosity and with fine and regular gas cells. However each kind of bread has its own special cell structure requirements and therefore there is no single standard which can be applied to all products (Cauvain, 2009). In panettone samples, variations in cell distribution and in the values of number of cells (n), total cell area $\left(\mathrm{mm}^{2}\right)$, mean cell area $\left(\mathrm{mm}^{2}\right)$ and ratio cell area to total area were found for all samples. However, the analysis of these characteristics evaluated in Table IV showed no significant differences between the samples $(p \geq 0.05)$. The highest and the lowest number of cells, respectively, were observed in samples F (830.50) and A (573.50). All the panettone samples showed a more open crumb structure. This phenomenon was especially evident for sample A, in which the highest value for mean cell area was observed; sample F presented the lowest value. Samples A $\left(2195.23 \mathrm{~mm}^{2}\right)$ and I $\left(1666.89 \mathrm{~mm}^{2}\right)$ showed, respectively, the highest and the lowest values for total cell area.

As observed in Figure 1, different shapes and areas for cells in each sample were found. These results of the obtained crumb grain features demonstrate that there is product variability even in commercial samples, and that it is also quite complicated to obtain baked goods with standard characteristics when a well-established production technology is used. Each type of product presents its own special cell structure and therefore there is not a unique pattern which can be applied to all products (Angioloni, Collar, 2009).

TABLE IV - Image analysis of crumb structure of panettone samples

\begin{tabular}{lcccc}
\hline Sample & $\mathrm{N}^{\circ}$ Cells $(\mathrm{n})$ & Total cell area $\left(\mathrm{mm}^{2}\right)$ & Mean cell area $\left(\mathrm{mm}^{2}\right)$ & Cell area/total area ratio \\
\hline $\mathrm{A}$ & $573.50 \pm 238.29$ & $2195.23 \pm 352.33$ & $4.33 \pm 2.41$ & $0.44 \pm 0.07$ \\
$\mathrm{~B}$ & $705.00 \pm 24.04$ & $1846.91 \pm 349.41$ & $2.61 \pm 0.41$ & $0.37 \pm 0.07$ \\
$\mathrm{C}$ & $778.50 \pm 75.66$ & $1705.22 \pm 133.98$ & $2.19 \pm 0.04$ & $0.34 \pm 0.03$ \\
$\mathrm{D}$ & $642.50 \pm 115.26$ & $1901.48 \pm 226.30$ & $3.04 \pm 0.90$ & $0.38 \pm 0.05$ \\
$\mathrm{E}$ & $624.00 \pm 169.71$ & $2093.40 \pm 144.12$ & $3.52 \pm 1.19$ & $0.42 \pm 0.03$ \\
$\mathrm{~F}$ & $830.50 \pm 10.61$ & $1728.52 \pm 109.00$ & $2.08 \pm 0.10$ & $0.35 \pm 0.02$ \\
$\mathrm{G}$ & $766.50 \pm 284.96$ & $1816.91 \pm 17.33$ & $2.54 \pm 0.92$ & $0.36 \pm 0.00$ \\
$\mathrm{H}$ & $752.00 \pm 29.70$ & $1685.25 \pm 92.09$ & $2.25 \pm 0.21$ & $0.34 \pm 0.02$ \\
$\mathrm{I}$ & $594.50 \pm 102.53$ & $1666.89 \pm 341.18$ & $2.90 \pm 1.07$ & $0.33 \pm 0.07$ \\
p-ANOVA & 0.35 & 0.12 & 0.48 & 0.12 \\
\hline
\end{tabular}

aProbability value obtained by one-way analysis of variance. 

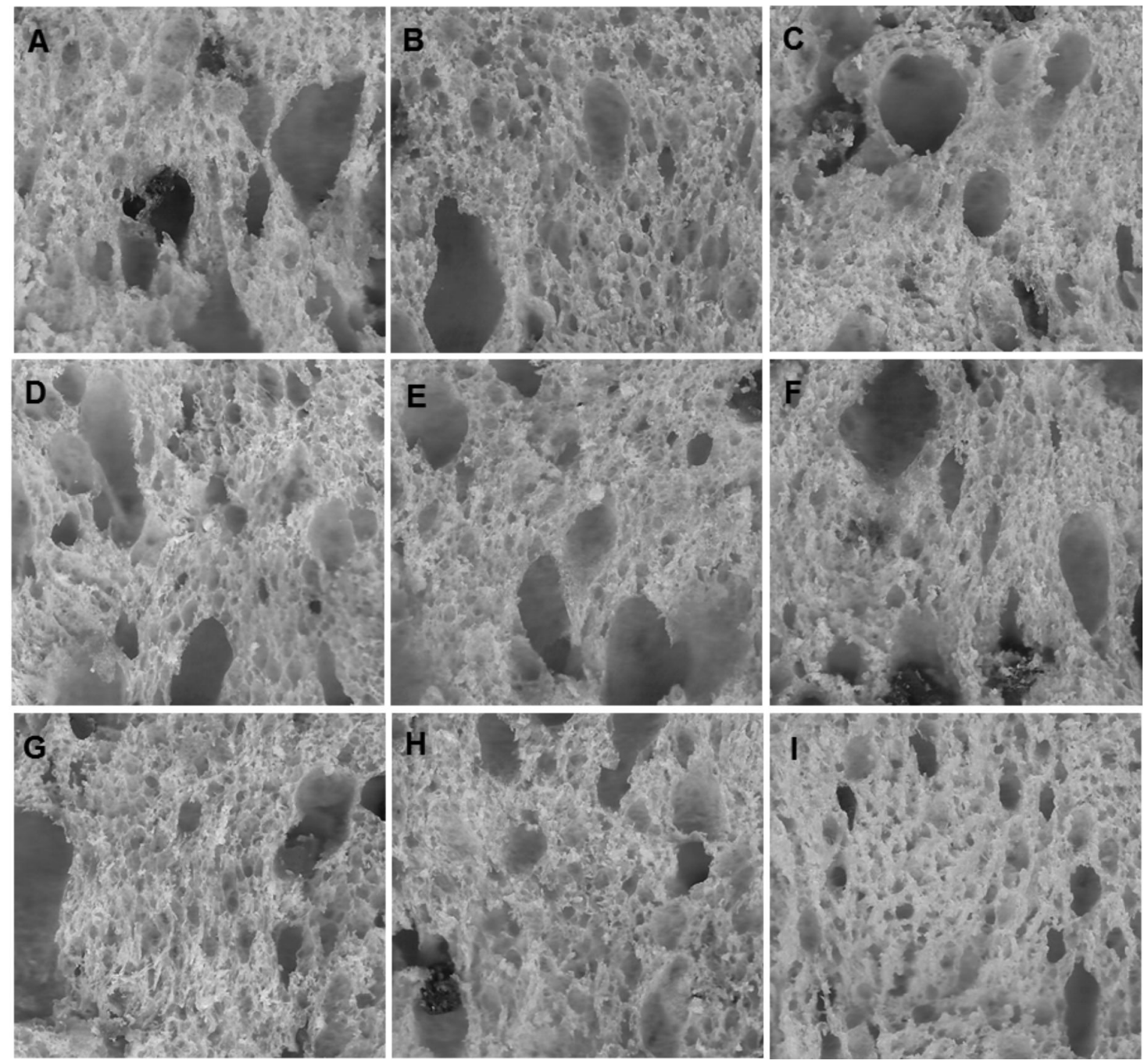

FIGURE 1 - Image analysis of crumb structure of different commercial panettone samples (60 mm x $60 \mathrm{~mm}$ area).

\section{CONCLUSIONS}

The physical and physicochemical analyses performed on panettone samples available in the Brazilian market were shown to be useful for better characterization of this product. The results described for the studied parameters indicated heterogeneity among the values, which might be related mainly to the production process, formulation and storage of samples. In relation to the manufacture dates of the products, it was observed that these were not correlated with the measured parameters. In these products, the shelf life did not have an impact on the results.

\section{ACKNOWLEDGMENTS}

The authors would like to thank the Conselho Nacional de Desenvolvimento Científico e Tecnológico
(CNPq) for the scholarship granted to the first author.

\section{REFERENCES}

AGENCIA NACIONAL DE VIGILÂNCIA SANITÁRIA - ANVISA. Resolução RDC n.263, de 22 de setembro de 2005. Regulamento técnico para produtos de cereais, amidos, farinhas e farelos. Diário Oficial da Republica Federativa do Brasil, Poder Executivo, Brasília, DF, 23 de setembro 2005. Available at: $<\mathrm{http}: / / \mathrm{e}-$ legis.anvisa.gob.br. $>$ Accessed on: 25 jan. 2012.

AGENCIA NACIONAL DE VIGILÂNCIA SANITÁRIA ANVISA. Resolução RDC no. 90, de 18 de outubro de 2000. Regulamento técnico para fixação de identidade e qualidade de pão. Diario Oficial da República Federativa do Brasil, Brasília, DF, out. 2000. Available at: <http:// www.anvisa.gov.br> Accessed on: 04 jun. 2012. 
ALTAMIRANO-FORTOUL, R.; ROSELL, C.M. Physicochemical changes in breads from bake off Technologies during storage. LWT - Food Sci. Technol., v.44, p.631-636, 2011 .

\section{AMERICAN ASSOCIATION OF CEREAL CHEMISTS.} Approved methods of the American Association of Cereal Chemists. 9th ed. St. Paul: AACC, 1995. 1200 p.

ANGIOLONI, A.; COLLAR, C. Bread crumb quality assessment: a plural physical approach. Eur. Food Res. Technol., v.229, p.21-30, 2009.

BENEJAM, W.; STEFFOLANI, M.E.; LEÓN, A.E. Use of enzyme to improve the technological quality of a panettone like baked product. Int. J. Food Sci. Technol., v.44, p.2431$2437,2009$.

BOURNE, M.C. Food texture and viscosity: concept and measurement. 2.ed. San Diego: Academic Press, 2002. $400 \mathrm{p}$.

CAUVAIN, S.P. Improving the control of staling in frozen bakery products. Trends Food Sci. Technol., v.9, p.56-61, 1998

CAUVAIN, S.P. The relevance of testing to the manufacture of bread and fermented products. In: CAUVAIN, S.P.; YOUNG, L.S. (Eds.) The ICC handbook of cereals, flour, dough and product testing: methods and applications. Pennsylvania: DEStech Publications, Inc., 2009. cap.6, p.125-155.

ESTELLER, M.S.; AMARAL, R.L.; LANNES, S.C.S. Effect of sugar and fat replacers on the texture of baked goods. $J$. Texture Stud., v.35, p.383-393, 2004.

ESTELLER, M.S.; LANNES, S.C.S. Parâmetros complementares para fixação de identidade e qualidade de produtos panificados. Ciênc. Tecnol Alim., v.25, p.802806, 2005.

ESTELLER, M.S.; LIMA, A.C.O.; LANNES, S.C.S. Color measurement in hamburger buns with fat and sugar replacers. LWT - Food Sci. Technol., v.39, p.184-187, 2006.

FARAHNAKY, A.; MAJZOOBI, M. Physicochemical properties of partbaked breads. Int. J. Food Properties, v.11, p.186-195, 2008.
GALLAGHER, E.; GORMLEY, T.R.; ARENDT, E.K. Crust and crumb characteristics of gluten free breads. J. Food Eng., v.56, p.153-161, 2003.

GÄNZLE, M.G.; EHMANN, M.; HAMMES, W.P. Modeling of growth of Lactobacillus sanfranciscensis and Candida milleri in response to process parameters of sourgdough fermentation. Appl. Environ. Microbiol., v.64, p.2616-2623, 1998.

GAROFALO, C.; SILVESTRI, G.; AQUILANTI, L.; CLEMENTI, F. PCR-DGGE analysis of lactic acid bacteria and yeast dynamics during the production processes of three varieties of panettone. J. Appl. Microbiol., v.105, p.243-254, 2008.

GIESE, J. Color measurement in foods as a quality parameter. Food Technol. Chicago, v.54, p.62-63, 2000.

HANSEN, A.; HANSEN, B. Flavour of sourdough wheat bread crumb. Z. Lebensm. Unters Forsch., v.202, p.244-249, 1996.

HOSENEY, R.C. Principles of cereal science and technology. 2.ed. St. Paul: AACC Inc., 1994. 378 p.

KENNY, S.; WEHRLE, K.; STANTON, C.; ARENDT, E.K. Incorporation of dairy ingredients into wheat bread: effects on dough rheology and bread quality. Eur. Food Res. Technol., v.210, p.391-396, 2000.

LAI, H.M.; LIN, T.C. Bakery products. In: HUI, Y.H. (Ed). Handbook of food science, technology, and engineering. Boca Raton: CRC Press, 2006. v.4, cap.148, p.1-52.

NISHITA, K.D.; ROBERTS, R.L.; BEAN, M.M. Development of a yeast-leavened rice-based formula. Cereal Chem., v.53, p.626-634, 1976.

O'BRIEN, C.M.; MUELLER, A.; SCANNELL, A.G.M.; ARENDT, E.K. Evaluation of the effect of fat replacers on the quality of wheat bread. J. Food Eng., v.56, p.265-267, 2003.

RIBOTTA, P.D.; PÉREZ, G.T.; AÑÓN, M.C.; LEÓN, A.E. Optimization of additive combination for improved soywheat bread quality. Food Bioprocess Technol., v.3, p.395405, 2010. 
RANDAZZO, C.L.; HEILIG, H.; RESTUCCIA, C.; GIUDICI, P.; CAGGIA, C. Bacterial population on traditional sourdough evaluated by molecular methods. J. Appl. Microbiol., v.99, p.251-258, 2005.

ROSENTHAL, A.L. Textura de los alimentos: medida y percepción. Zaragosa: Acribia, 2001.311 p.

SCANLON, M.G.; ZGHAL, M.C. Bread properties and crumb structure. Food Res. Int., v.34, p.841-864, 2001.
VOGEL, R.F.; KNORR, R.; MÜLLER, M.R.A.; STEUDEL, U.; GÄNZLE, M.G.; EHRMANN, M. Non-dairy lactic fermentations: the cereal world. Anton. Leeuw., v.76, p.403411, 1999.

Received for publication on $19^{\text {th }}$ June 2012 Accepted for publication on $3^{\text {rd }}$ January 2013 